\title{
Income Inequality and Subjective Well-being: A Cross-National Study on the Conditional Effects of Individual and National Characteristics
}

\author{
Jesper Rözer • Gerbert Kraaykamp
}

Accepted: 10 July 2012/Published online: 11 August 2012

(C) Springer Science+Business Media B.V. 2012

\begin{abstract}
In this study we raise the question how a nation's income inequality affects subjective well-being. Using information on 195,091 individuals from 85 different countries from the World Value Surveys and the European Value Surveys, we established that in general, people living in more unequal countries report higher well-being than people from more equal countries. This association however does not apply to all people similarly. First, the positive effect of a nation's income inequality is weaker when individuals express more social and institutional trust, and underscore egalitarian norms to a larger extent. Second, the positive association between national income inequality and subjective wellbeing is less strong for people from countries with high levels of social and institutional trust. So, our research predominantly indicates that there are far-reaching effects of an individual's and a nation's trust on people's well-being.
\end{abstract}

Keywords Subjective well-being - Income inequality · Cross-level interactions . World Value Survey · European Value Survey

\section{Introduction}

In many countries, governments, especially from the political left, put effort in reducing income inequality. These endeavors certainly have various objectives, but one of them obviously is to improve people's well-being. Indeed, numerous studies underscore that a nation's income inequality is related to feelings of subjective well-being within the population. Current knowledge about this relation, however, is still inconclusive, since results

\footnotetext{
J. Rözer

Department of Sociology/ICS, Utrecht University, Heidelberglaan 2, Utrecht, The Netherlands e-mail: j.j.rozer@uu.nl

J. Rözer

Department of Sociology/ICS, Utrecht University, Padualaan 14, Utrecht, The Netherlands

G. Kraaykamp $(\bowtie)$

Department of Sociology/ICS, Radboud University, Nijmegen, The Netherlands

e-mail: g.kraaykamp@maw.ru.nl
} 
so far are mixed (Schneider 2011a; Ram 2010; Verme 2011; Bjørnskov et al. 2010). For example, using a comparative design, Verme (2011) exemplifies that a nation's income inequality reduces feelings of well-being, while Berg and Veenhoven (2010) conclude the opposite in their worldwide cross-sectional research. More congruent results are found for countries that are to some extent homogenous with respect to their attributes. For instance, income inequality seems to reduce happiness ${ }^{1}$ in continental European countries such as Germany and France, and in Latin American countries, such as Brazil and Peru (Graham and Pettinato 2002; Schwarze and Härpfer 2002; Alesina et al. 2004; Fahey and Smyth 2004; O'Connell 2004; Graham and Felton 2005). In contrast, it seems to enhance happiness in Anglo-Saxon countries, such as the United States and Great Britain (Tomes 1986; Clark 2003; Hagerty 2000; Alesina et al. 2004). As a result we may conclude that the association between income inequality and subjective well-being is affected by tangible national characteristics. Additionally, individual features possibly influence the relationship between income inequality and subjective well-being. For instance, personal norms related to inequality and (perceived) income have been found to be influential (Biancotti and D'Alessio 2008; Bjørnskov et al. 2010; Fischer 2009). Keeping the results of prior research in mind, in this study we aim to detect under what specific conditions a nation's income inequality works out positively or negatively when it comes to subjective wellbeing. Our research question therefore reads: How does the relation between national income inequality and subjective well-being differ between countries worldwide, and to what extent do individual and national characteristics affect this relation?

To study differentiated effects of a nation's income inequality we examine interactions that test to what extent individual and national characteristics affect the association between income inequality and feelings of well-being. Our study advances upon earlier works that looked at conditional effects (Biancotti and D'Alessio 2008; Bjørnskov et al. 2010; Fischer 2009; Beja 2011; Alesina et al. 2004) in several ways. First and most importantly, we consider several innovative hypotheses and put them to the test simultaneously. For example, at the country level we look at the (interaction) effects of national wealth, social trust, and trust in a nation's institutions. At the individual level we are to our knowledge the first to test simultaneously the (interaction) effects of a person's reported social and institutionalized trust. Second, these national and individual characteristics will be directly linked to income inequality (in interaction), and thus can explicate how exactly national income inequality affects subjective wellbeing (Rodger 2003; Bay and Pedersen 2006; Juul 2010). Third, we use the world's largest combination of datasets (all waves of the European Value Studies and World Value Studies) currently available to study how individual and national variables condition the relationship between well-being and income inequality. This makes the results of our analyses highly stable and ensures generalizability to a large extent. Finally, we use advanced multilevel models to account for the fact that individuals are nested within countries.

\section{Theoretical Background and Hypotheses}

Our theoretical interests lie with differences in the relation between national income inequality and individual feelings of well-being, and the extent to which individual and

\footnotetext{
1 We are aware of the different connotations of the terms subjective well-being, happiness, satisfaction, and quality of life. These factors, however, seem highly correlated and are often used as interchangeable (Veenhoven 1984, 2008). Especially in happiness research this seems standard practice (e.g. Easterlin 2001; Alesina et al. 2004; Verme 2011).
} 


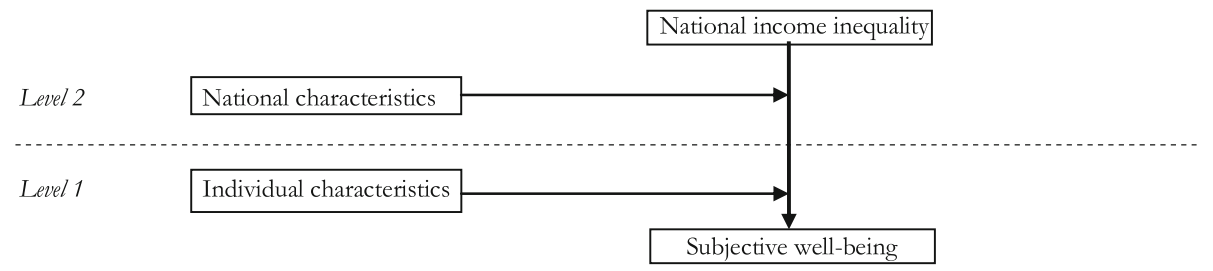

Fig. 1 Visual representation of theoretical multi-level structure with cross-level and within level interactions

national characteristics condition this relation. These relations are depicted in Fig. 1. The association between national income inequality and subjective well-being is displayed at the right hand side of the figure. In our theory section, we start discussing the main effect between income inequality and subjective well-being. Next, we address cross-level interactions of individual features with income inequality. Subsequently, national level interactions, or so-called within-level interactions, will be discussed.

\subsection{National Income Inequality and Individual Subjective Well-Being}

In the relevant literature various partly contrasting mechanisms have been suggested to explain the relationship between a nation's income inequality and individual subjective well-being. On the one hand, income inequality in a country is sometimes considered to be a necessary condition to create incentives to be economically active and competitive (Clark 2003; Alesina et al. 2004; Verme 2011). Additionally, a country's economic policy of liberty and entrepreneurship may enlarge income inequality, but it is also thought to lead to greater economic prosperity and the perception of individual accountability for success in its population (De Haan and Sturm 2000; Friedman 1962; Nozick 1974). Hence, in this perspective a nation's income inequality may be related to higher personal well-being.

On the other hand, (large) income inequality is regularly believed to lower social trust and to divide a society (Kawachi et al. 1997; Wilkinson and Picket 2009; Gustavsson and Jordahl 2008). Moreover, it is associated with problems such as poverty, deprivation and higher crime rates (Wilkinson and Picket 2009; Beja 2011; Cramer 2003), and it may contradict basic ideas of justice (Rawls 2006 [1971]; Alesina et al. 2004). From this point of view a nation's income inequality is likely to reduce a person's well-being.

Various empirical studies have reported on the relation between income inequality and subjective well-being (Ram 2010; Verme 2011; Bjørnskov et al. 2010; Schneider 2011b). Unfortunately, results from these investigations so far are rather inconclusive. There is no straightforward conclusion about whether the relationship between income inequality and personal well-being is positive or negative. Primarily this leads us to question whether the relation may be dependent on various individual and national characteristics. Below we therefore provide several ideas about how individual and national characteristics may condition the relation between income inequality and well-being. In formulating our hypotheses we are mainly interested in the direction of the conditional effects and their effect size. For matters of readability, we however presuppose a positive relationship between national income inequality and subjective well-being (preluding on empirical results) when formulating our hypotheses. However, in our discussion of hypotheses we only stress the direction of the conditional effects. 
2.2 Cross-Level Interactions: National Income Inequality with Individual Features

\subsubsection{Individual Perceived Income}

Traditionally, personal income is seen as a key variable that determines how people's wellbeing is affected by income inequality in a country. Disadvantaged people are likely to be the ones who will face a loss of income when income inequality increases, while affluent people will probably gain money in this situation (given a constant total income). Actual income may thus enhance feelings of individual well-being because it provides a person with the opportunity to acquire (material) goods. In this respect, several studies have shown that relative (or perceived) income, the income people perceive to have compared to others, is even more important than actual income when it comes to well-being (Easterlin 2001; Clark et al. 2008; Linsen et al. 2011). People foremost like to 'Keep up with the Jones', and consequently, it is not (only) actual income that is relevant but their relative position in a country's income distribution (e.g. Luttmer 2005; Rojas 2007; Clark et al. 2008). Therefore, assuming a positive relation between income inequality and subjective well-being, we hypothesize that the higher an individual's perceived income, the more positive the relation between income inequality and subjective well-being will be.

\subsubsection{Individual Egalitarian Norms}

Next, individual norms and opinions regarding social inequality may be relevant for the relation between income inequality and subjective well-being. As cognitive dissonance theory implies, people experience cognitive strains and stress when the circumstances they face are not in accordance to their personal norms (Festinger 1957). In a situation of large income disparity, this actually is the case for people who value egalitarian norms. Accordingly, it makes them suffer from feelings of injustice and strain which may reduce their well-being. Accordingly, we expect the more people hold egalitarian norms, the less positive the relation between income inequality and subjective well-being will be.

\subsubsection{Individual Social Trust}

An individual's level of social trust may also determine how subjective well-being is affected by income inequality. Trust in (general) others makes people dare to step outside their own world which enhances their interest in people in general (Putnam 2000; Coleman 1988). Contacts with other people increase mutual understanding which may lead to feelings of solidarity. This can be observed in the pro-social behavior of those who score high on social trust. They give more money to charity, are more active in voluntary work, and are relatively tolerant towards ethnic minorities and people living on welfare (Scheepers et al. 2002; Rothstein and Uslaner 2005; Nannestad 2008). Because of this overall solidarity and the large number of contacts trustful people are likely to have across social strata, it is reasonable to suspect that trustful people will experience more strain, faced with large income differences, than those with lower levels of social trust. Therefore, we expect that the higher people's social trust, the less positive the relation between income inequality and subjective well-being will be.

\subsubsection{Individual Institutionalized Trust}

Institutionalized trust indicates that an individual has confidence in and relies on a nation's organizations, such as the police, courts of justice, and the government. Most likely, this 
trust is based on people's own experiences with such organizations. People scoring high on institutionalized trust presume that a country's institutions are honest and fair and are not corrupt. Moreover, they assume that these institutions are well organized, and consequently, it is expected that they have more confidence in society as a whole (Heitmeyer 2004; Hetherington 2004; Hudson 2006). Having faith in society and its institutions strengthens the idea that governmental policy might be effective in bringing about change and reduce unfairness. Subsequently, people who trust their national institutions may be dissatisfied when little is done about large income disparity (Rothstein and Uslaner 2005). We therefore hypothesize that the higher people's institutionalized trust, the less positive the relation between income inequality and subjective well-being will be.

\subsection{Within-Level Interactions: National Income Inequality with Country Characteristics}

\subsubsection{National Wealth}

At the country level, we first suppose that general wealth and prosperity affects how income inequality is related to subjective well-being. From a hierarchy of needs perspective (Maslow 1954; Inglehart 1977, 1990), it can be argued that most people in less affluent countries more or less deal with inequality as a standard arrangement. In contrast, in more wealthy societies people have the time, moral standards and resources to reflect on problems related to poverty and inequality (Inglehart 1977, 1990; Beja 2011). Accordingly, people in wealthier countries may have trouble with the moral implications of large income disparities which decreases their well-being. Therefore, we hypothesize that the wealthier the country that people live in, the less positive the relation between income inequality and subjective well-being will be.

\subsubsection{National Social Trust}

Next, it seems important that in countries with many trustful inhabitants social opinions regarding income inequality and the less fortunate may develop into general norms influencing every individual in society: not only those who are trustful themselves (Jordahl 2007; Delhey and Newton 2005; Rohstein and Uslaner 2005). At the country level, social trust then becomes an attribute of society (Portes 2000). For our research, two aspects of social trust are considered to be important. First, a high level of social trust in a country may reflect the degree of social control; trustful people simply have more ties with distinct others than people scoring low on social trust. Second, and more importantly, it reflects an overall sense of solidarity in society; people in such countries are more concerned about distinct others (Coleman 1988; Putnam 2000; Portes 2000). We presume that this combination of social connections, control and high levels of solidarity cause that people are more often dissatisfied with negative side effects of income inequality (Rothstein and Uslaner 2005). Hence, we expect that the higher the level of general social trust is in the country that people live in, the less positive the relation between income inequality and subjective well-being will be.

\subsubsection{National Institutionalized Trust}

An adjacent aspect of a nation's trust level lies with the reputation of its institutions among its citizens. On the country level, obviously trust in a nation's institutions will be greater 
when institutions are capable to establish and preserve general societal rules and norms. General norms of overall respect and tolerance have to be prominent in a country to maintain a wide-ranging agreement that all (or most) citizens are connected and constitute a country (Svendsen and Bjørnskov 2007; Lister 2009; Rothstein and Uslaner 2005). As a side effect, these norms may put a negative mark on large inequalities. Contrastingly, when norms on the non-alignment of the institutions are not widely shared, the legitimacy of a country's constitution may be questioned (Heitmeyer 2004; Hetherington 2004; Hudson 2006). In such a situation, people are less likely to be confronted with the negative consequences of high levels of income inequality. We thus expect that the higher general institutionalized trust is in the country that people live in, the less positive the relation between income inequality and subjective well-being will be.

\section{Data and Measurements}

\subsection{The World Value Survey and European Value Survey}

To test our hypotheses we combined two of the largest datasets in the world: the World Value Survey (WVS) and the European Value Survey (EVS). We employed all surveys held between 1989 and 2008. From these surveys we used information of 195,091 individuals living in 85 different countries. Two questions on well-being had to be available to include a country (in a year) in our sample. Countries (in a year) were also excluded when it was found impossible to gather information on national income inequality or wealth. We only employed countries (in a year) and respondents without missing values on the crucial independent variables. We restricted our sample to people aged 18 years or older to assess comparability between the various surveys. Despite some oversampling of Western countries, all large regions of the world are represented. Over $90 \%$ of the surveys cover a standard of at least 1,000 respondents. The average sample size per country-year combination is 1,403 respondents. All questioning was conducted in face-to-face interviews. Random sampling assured that the surveys are representative within a country (WVS 1981-2008).

\subsection{Measurements}

To describe their subjective well-being people use both affective and cognitive qualities. Individuals estimate their affective state of mind to assess how happy they feel, and use their cognitive abilities to compare life as it is with how they would like it to be. Both concepts of happiness and satisfaction together constitute people's subjective well-being (Haller and Hadler 2006; Veenhoven 2008). In our study satisfaction was measured with the question 'All things considered, how satisfied are you with your life as a whole nowadays?' Answers ranged from dissatisfied (0) to satisfied (9). Happiness was measured with the question 'Taking all things together, how happy would you say you are?', with answering categories ranging from very happy (0) to not happy at all (3). For our analyses we calculated the mean of both measures after we rescaled happiness to ranging from 0 to 9. The average score of our subjective well-being measure equals 5.9 scale points. Descriptive statistics of all our variables are displayed in Table 1.

Surely it can be questioned whether both items measure subjective well-being to the same extent (Bjørnskov et al. 2010). We presume, however, that a combination of both items comes closest to people's everyday experience and captures subjective well-being 
Table 1 Descriptive statistics

\begin{tabular}{|c|c|c|c|c|c|}
\hline & $\mathrm{N}$ & Min & Max & Mean & SD \\
\hline \multicolumn{6}{|l|}{ Individual characteristics } \\
\hline Subjective well-being & 195,091 & 0 & 9 & 5.875 & 2.036 \\
\hline Perceived relative income & 177,054 & 0 & 9 & 3.649 & 2.448 \\
\hline Egalitarian norms & 195,091 & 0 & 9 & 4.869 & 2.997 \\
\hline Social trust & 195,091 & 0 & 1 & .276 & .447 \\
\hline Institutional trust & 195,091 & 0 & 3 & 1.440 & .731 \\
\hline Educational level & 195,091 & 0 & 8 & 4.602 & 2.308 \\
\hline \multicolumn{6}{|l|}{ Main activity } \\
\hline Full time & 195,091 & 0 & 1 & .377 & .485 \\
\hline Part time & 195,091 & 0 & 1 & .074 & .261 \\
\hline Self employed & 195,091 & 0 & 1 & .098 & .297 \\
\hline Retired & 195,091 & 0 & 1 & .147 & .354 \\
\hline Housewife & 195,091 & 0 & 1 & .132 & .338 \\
\hline Student & 195,091 & 0 & 1 & .062 & .241 \\
\hline Unemployed & 195,091 & 0 & 1 & .090 & .286 \\
\hline Other & 195,091 & 0 & 1 & .021 & .142 \\
\hline \multicolumn{6}{|l|}{ Marital status } \\
\hline Married & 195,091 & 0 & 1 & .597 & .491 \\
\hline Together & 195,091 & 0 & 1 & .055 & .228 \\
\hline Divorced & 195,091 & 0 & 1 & .038 & .191 \\
\hline Separated & 195,091 & 0 & 1 & .017 & .131 \\
\hline Widowed & 195,091 & 0 & 1 & .065 & .247 \\
\hline Single & 195,091 & 0 & 1 & .228 & .419 \\
\hline \multicolumn{6}{|l|}{ Denomination } \\
\hline None & 195,091 & 0 & 1 & .171 & .377 \\
\hline Buddhist & 195,091 & 0 & 1 & .022 & .147 \\
\hline Muslim & 195,091 & 0 & 1 & .123 & .329 \\
\hline Protestant & 195,091 & 0 & 1 & .121 & .326 \\
\hline Catholic & 195,091 & 0 & 1 & .327 & .469 \\
\hline Orthodox & 195,091 & 0 & 1 & .119 & .324 \\
\hline Jew & 195,091 & 0 & 1 & .002 & .046 \\
\hline Hindu & 195,091 & 0 & 1 & .030 & .170 \\
\hline Other Christian & 195,091 & 0 & 1 & .073 & .260 \\
\hline Other & 195,091 & 0 & 1 & .023 & .151 \\
\hline Church attendance & 195,091 & 0 & 104 & 24.311 & 35.212 \\
\hline Age & 195,091 & 18 & 99 & 41.826 & 16.162 \\
\hline Gender & 195,091 & 0 & 1 & .484 & .500 \\
\hline \multicolumn{6}{|l|}{ Country characteristics } \\
\hline Gini & 195,091 & .200 & .650 & .380 & .108 \\
\hline GDP per capita $(10,000$ USdollars $)$ & 195,091 & .019 & 5.501 & 1.234 & 1.034 \\
\hline National social trust & 195,091 & .028 & .742 & .276 & .140 \\
\hline National institutional trust & 195,091 & .808 & 2.611 & 1.433 & .302 \\
\hline
\end{tabular}

Source World Value Survey and European Social Survey (1989-2008) 
best. Yet, this does not imply that both items indicate exactly the same phenomenon. For instance, professionals may be satisfied by what they have accomplished, but unhappy about their stressful lives (Baker et al. 2005; Greenfield and Marks 2004). Indeed, in our sample the correlation between happiness and satisfaction is rather mediocre $(\mathrm{R}=.513)$. Another reason for this relatively low correlation might be that satisfaction is initially measured on a 10-point scale, while happiness is measured on a 4-point scale. This might have concealed subtle differences in the answering which obviously lowers the association. Surveys such as the General Social Survey and the European Social Survey included both questions on a 10-point scale, which showed substantially higher correlations. In our opinion, this indicates that both items can be analyzed in concordance.

We now discuss our individual level variables. Perceived (relative) income was measured as the perceived relative position of a respondent in a country. Answering categories were rescaled, with 0 indicating that a respondent belongs to the lowest income category, and 9 belonging to the highest income category. The question in the EVS and WVS that comes closest to measuring a person's egalitarian norms is the statement: 'Incomes should be made more equal versus we need larger income differences as incentives'. Answers ranged from preferring total inequality (0) to total equality (9). A person's social trust was measured by the standard question: 'Do you think most people can be trusted (1), or that you cannot be careful enough in dealing with people (0)?' Respondents were also asked a question about their institutionalized trust. More specifically they were asked how much confidence they had in national institutions like the police, parliament, and the system of justice. Scores ran from none at all (0) to a great deal (3). Average scores were taken to constitute a scale.

Next, we discuss the national level variables. Gini-coefficients were used to measure national income inequality. We employed the World Income Inequality Database, which is the most reliable and comparable data source on income inequality currently available. National wealth of a country was measured with GDP per capita in purchasing power parities from the Penn's World Trade Tables. GDP was transformed using the natural logarithm to ensure that the relation is linear. Country levels of social trust and institutional trust are represented by the aggregated scores of all respondents in a nation on the questions referring to individual social trust and institutional trust.

We used several control variables. A person's educational level was measured from no completed formal education (0) to university/college (7). Unfortunately, this education variable had many missing values. We imputed missing values using information in the EVS and WVS about the age at which people finished day-time education and other relevant factors. ${ }^{2}$ To indicate religious denomination we used the following ten categories: Buddhist, Muslim, Protestant, Roman Catholic, Orthodox Catholic, Jewish, Hindu, other Christian, other religion, and not belonging to a denomination. Religious attendance is measured with eight categories ranging from practically never to more than once a week. To use it as an interval variable we recoded these categories to actual attendance ranging from 0 to 104 times per year. A respondent's work status was indicated by eight dummy variables: full-time employed, part-time employed, self-employed, unemployed, retired, being a housewife, being a student and otherwise. Marital status was recoded into six

\footnotetext{
${ }^{2}$ Multilevel estimates with an additional random error were used to calculate imputed values. To maintain the same scaling, we used the restriction that the estimates could not become smaller than 0 or larger than 7 . We presume single level imputations are justified because of the high correlation between both items $(\mathrm{r}=.809)$.
} 
categories: married, cohabitation, divorced, separated, widowed, and single. Age ranged from 18 till 99 years and gender was coded 0 for women and 1 for men.

\section{Analyses}

In our dataset, individuals are nested within country-period combinations. To avoid the underestimation of standard errors, possibly leading to a confirmation of hypotheses too early, multilevel analyses are conducted (Snijders and Bosker 1999). We control for timedependency through the inclusion of year dummies to our models. ${ }^{3}$

In Table 2 we present five models that build up in complexity. Model 0, the base-line model, is used to calculate the Intra Class Correlation (ICC) which is .181 (.724/ $(.724+3.284))$. This indicates that $18.1 \%$ of the variance in subjective well-being is found at the country-year level, which means that there is substantial clustering within country-years and that it is appropriate to employ multilevel regression analyses.

Model 1 addresses the individual aspects. As expected it is observed that people who are higher educated and married hold higher levels of well-being than lower educated and unmarried people. Also, working in full-time paid employment is found to be advantageous as compared to unemployment, retirement and part-time employment. Apparently, success on the labor market, in marriage and in education amplifies a person's well-being. In general, Buddhists and Christians report higher levels of well-being than the unreligious and people with other faiths. Age shows its typical U-shape form; life seems to be most troublesome between the ages of 20 and 50. Women in general seem to feel slightly better than men.

As expected, a person's perceived income induces his/her feelings of well-being $(\mathrm{b}=.123)$; individual affluence to some extent pays off in terms of happiness. Contrastingly, people who value egalitarianism seem to express lower feelings of well-being $(\mathrm{b}=-.235)$. Finally, trust is important. Both trust in others $(\mathrm{b}=.232)$ and in institutions $(b=.263)$ lead people to feel better.

Model 2 includes the national level characteristics. In our worldwide sample, a country's income inequality has a positive effect on feelings of well-being $(b=2.861)$; people in unequal parts of the world seem to be happier than their counterparts in more equal countries. Note that the effects vary greatly depending on the specific continent countries are selected from. For instance, for people in Europe income inequality negatively affects well-being (significant: models not reported). Our results further indicate that in wealthier countries (GDP) citizens appear to express higher levels of subjective well-being $(\mathrm{b}=1.115)$. And, people living in countries with high trust in institutions also show more satisfaction with their current life $(b=.551)$. Moreover, we did not find any significant effect of a nation's social trust level. ${ }^{4}$

Model 3 includes the cross-level interactions; significant interactions derived from Model 3 are graphically displayed in Fig. 2. It is shown that individuals with high levels of social and institutionalized trust (in all situations of income inequality) report higher

\footnotetext{
${ }^{3}$ To test whether the assumptions underlying multilevel regression were not violated, we used the Influence.Me package for R (Nieuwehuis and Te Grotenhuis 2009) to test for outliers within a multilevel setting, and perturbations to test for collinearity and ill-conditioned data within a multilevel setting. These tests showed that our results are robust. We used the RealCom macro for MlWin (Goldstein et al. 2009) to (multiple) impute missing values on perceived relative income within our multilevel setting.

${ }^{4}$ This effect is mediated by national wealth; high social trusting countries are also wealthier (model not displayed).
} 
Table 2 Multi-level regression analysis of subjective well-being on individual characteristics, country characteristics, and cross-level and within level interactions, unstandardised coefficients

\begin{tabular}{|c|c|c|c|c|c|}
\hline & Model 0 & Model 1 & Model 2 & Model 3 & Model 4 \\
\hline Intercept & $5.848^{* *}$ & $6.253 * *$ & $4.102 * *$ & $4.707 * *$ & $1.914^{* *}$ \\
\hline \multicolumn{6}{|l|}{ Individual characteristics } \\
\hline Education & & $.036 * *$ & $.036^{* *}$ & $.030 * *$ & $.030 * *$ \\
\hline \multicolumn{6}{|c|}{ Main activitiy (ref: full time) } \\
\hline Part time & & $-.079 * *$ & $-.078 * *$ & $-.075 * *$ & $-.750^{* *}$ \\
\hline Self employed & & -.007 & -.006 & -.017 & -.017 \\
\hline Retired & & $-.060 * *$ & $-.060 * *$ & $-.065 * *$ & $-.066^{* *}$ \\
\hline House wife & & $.048 * *$ & $.049 * *$ & $.026 * *$ & $.026^{* *}$ \\
\hline Student & & $.037 * *$ & $.038 * *$ & .029 & $.029 \sim$ \\
\hline Unemployed & & $-.444 * *$ & $-.444 * *$ & $-.414 * *$ & $-.413^{* *}$ \\
\hline Other & & $-.067 * *$ & $-.066^{* *}$ & $-.079 * *$ & $-.079 * *$ \\
\hline \multicolumn{6}{|l|}{ Marital status (ref: married) } \\
\hline Together & & $-.228 * *$ & $-.227 * *$ & $-.222 * *$ & $-.223^{* *}$ \\
\hline Divorced & & $-.613 * *$ & $-.613 * *$ & $-.641 * *$ & $-.641 * *$ \\
\hline Separated & & $-.804 * *$ & $-.804 * *$ & $-.824 * *$ & $-.824 * *$ \\
\hline Widowed & & $-.644 * *$ & $-.644^{* *}$ & $-.638 * *$ & $-.638 * *$ \\
\hline Single & & $-.413 * *$ & $-.413 * *$ & $-.420 * *$ & $-.420^{* *}$ \\
\hline \multicolumn{6}{|l|}{ Denomination (ref: none) } \\
\hline Buddhist & & $.145^{* * *}$ & $.137 * *$ & $.138^{* *}$ & $.141 * *$ \\
\hline Muslim & & .008 & .010 & .022 & .022 \\
\hline Protestant & & $.211^{* *}$ & $.209 * *$ & $.193 * *$ & $.192 * *$ \\
\hline Catholic & & $.118^{* *}$ & $.118^{* *}$ & $.116^{* *}$ & $.115^{* *}$ \\
\hline Orthodox & & $-.090^{* *}$ & $-.088^{* *}$ & $-.074 * *$ & $-.074 * *$ \\
\hline Jew & & $-.200 * *$ & $-.201 * *$ & $-.164 * *$ & $-.163^{* *}$ \\
\hline Hindu & & $.102 * *$ & $.114 * *$ & $.108 * *$ & $.110^{* * *}$ \\
\hline Other Christian & & $.211^{* *}$ & $.210 * *$ & $.216^{* *}$ & $.213 * *$ \\
\hline Other & & -.048 & -.049 & .005 & .004 \\
\hline Church Attendance & & $.003 * *$ & .003 & $.003 * *$ & $.003 * *$ \\
\hline Age & & $-.059 * *$ & $-.059 * *$ & $-.056 * *$ & $-.056^{* *}$ \\
\hline $\mathrm{Age}^{2}$ & & $.001^{* *}$ & $.001 * *$ & $.001^{* *}$ & $.001 * *$ \\
\hline Gender (ref: women) & & $-.062 * *$ & $-.062 * *$ & $-.062 * *$ & $-.062 * *$ \\
\hline Egalitarian norms & & $-.235 * *$ & $-.236 * *$ & $-.126 * *$ & $-.125^{* *}$ \\
\hline Perceived income & & $.123 * *$ & $.232 * *$ & $.125^{* *}$ & $.126^{* *}$ \\
\hline Social trust & & $.232 * *$ & $.232 * *$ & $.459 * *$ & $.449 * *$ \\
\hline Institutional trust & & $.263 * *$ & $.236^{* *}$ & $.456^{* *}$ & $.453 * *$ \\
\hline \multicolumn{6}{|l|}{ Country characteristics } \\
\hline GDP (log) & & & $1.115^{* *}$ & $.884 * *$ & $.936^{* *}$ \\
\hline National social trust & & & .139 & -.301 & $2.481 * *$ \\
\hline National institutional trust & & & $.551 * *$ & $.389 * *$ & $1.831 * *$ \\
\hline Gini & & & $2.861 * *$ & $2.709 * *$ & $9.967 * *$ \\
\hline \multicolumn{6}{|c|}{ Cross Level Interactions (Gini by) } \\
\hline Perceived income & & & & .033 & .033 \\
\hline
\end{tabular}


Table 2 continued

\begin{tabular}{|c|c|c|c|c|c|}
\hline & Model 0 & Model 1 & Model 2 & Model 3 & Model 4 \\
\hline Egalitarian norms & & & & $-.063 * *$ & $-.063 * *$ \\
\hline Social trust & & & & $-.565^{* *}$ & $-.536^{* *}$ \\
\hline Institutional trust & & & & $-.482 * *$ & $-.475^{* *}$ \\
\hline \multicolumn{6}{|c|}{ National Level Interactions (Gini by) } \\
\hline GDP $(\log )$ & & & & & .063 \\
\hline National social trust & & & & & $-8.781^{* *}$ \\
\hline National institutional trust & & & & & $-3.753 * *$ \\
\hline Individual variance & 3.284 & 3.001 & 3.001 & 2.927 & 2.927 \\
\hline Intercept slope variance & .724 & .581 & .339 & .819 & .690 \\
\hline$-2 \mathrm{LL}$ (approximate) & 767,226 & 679,968 & 679,879 & 676,203 & 676,180 \\
\hline
\end{tabular}

Survey years are included in all models but are not reported and all variable included in interaction are random over countries

Source World Value Survey and European Value Survey (1981-2006)

** $P<0.01 ; * P<0.05 ; \sim P<0.10$

feelings of well-being than their low trusting counterparts. The differences, however, between low and high trusting individuals are smallest in the most unequal countries. In other words, the positive effect of income inequality becomes weaker with increasing levels of individual social and institutionalized trust $(b=-.565$ and $b=-.482$ respectively). Moreover, people who underscore egalitarian norms (in all situations of income inequality) indicate lower levels of well-being than people who put a lower value on equality. Yet, the difference between both groups is largest in the most unequal societies ( $b=-.063$ : i.e. the positive effect becomes weaker). We did not observe any significant interaction according to individual perceived income.

Model 4 presents the national (within) level interactions. Again significant interactions are displayed in Fig. 2. Our results confirm that the higher the general social and institutional trust is in a country, the weaker the positive effect of inequality on well-being is. The magnitude of the interactions between income inequality and social and institutional trust implies that people in high trusting societies only report higher levels of well-being than people in low trusting societies when a nation's inequality is low $(b=-8.781$ and $\mathrm{b}=-3.753$ respectively). No indications are found that national wealth affects the relationship between a country's income inequality and subjective well-being. So, our research predominantly underscores that there are important effects of (individual and national) trust on people's well-being.

\section{Conclusion and Discussion}

In social science there is an ongoing discussion about how income inequality precisely affects the subjective well-being of citizens. Prior research on this relation is rather inconclusive since results are mixed. To shed more light on this issue we combine information available from the World Value Surveys and the European Value Surveys. Using information on 195.091 individuals from 85 different countries around the world, we first established that people living in more unequal countries report significantly higher 

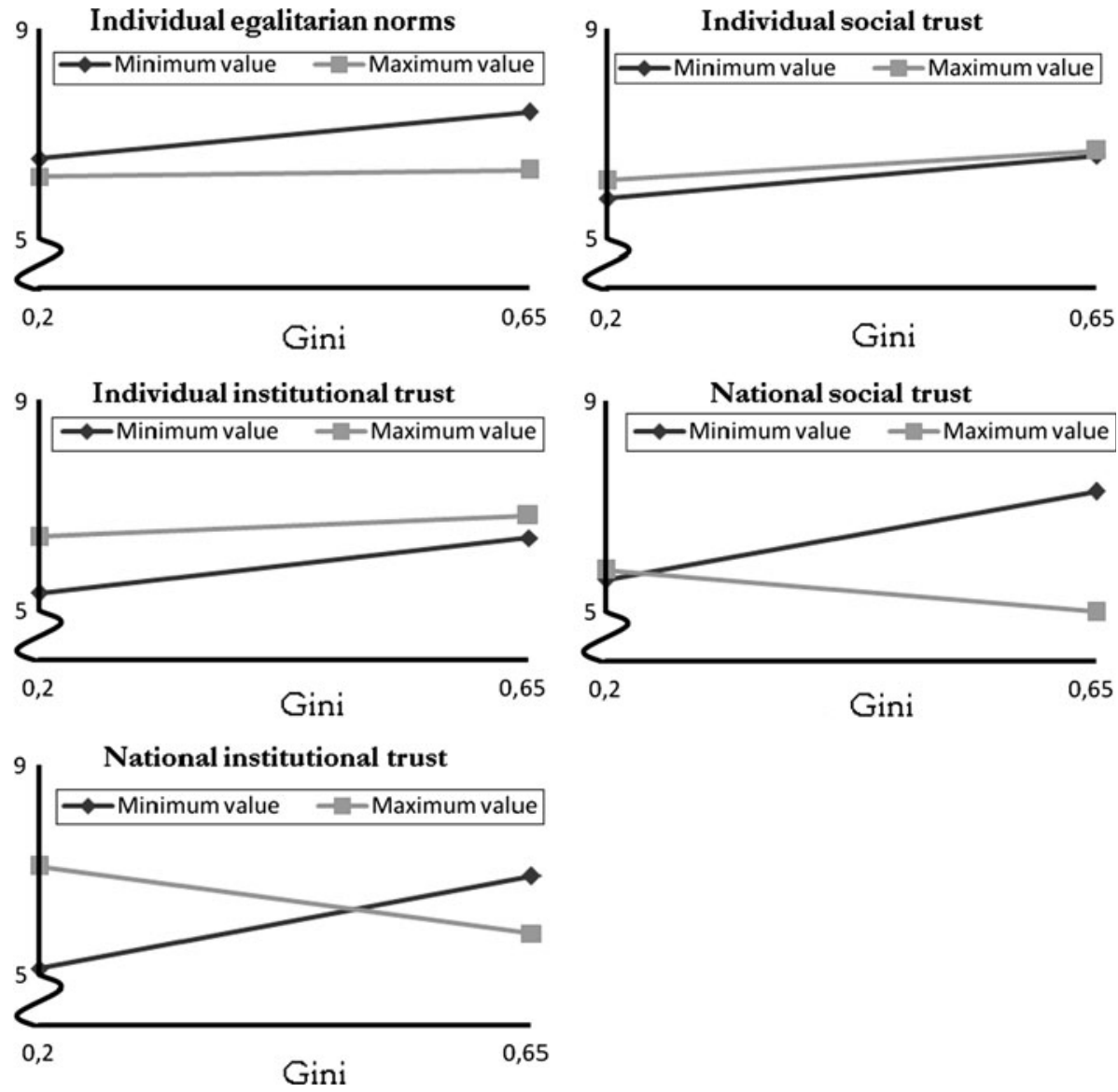

Fig. 2 The relationship of national income inequality (Gini) and subjective well-being related to minimum and maximum values on egalitarian norms, individual social trust, individual institutional trust, national social trust and national institutional trust

levels of well-being than their counterparts in more equal societies. Our results are in line with the previous world wide studies of Berg and Veenhoven (2010) and Haller and Hadler (2006). ${ }^{5}$ It, however, contradicts the findings of Bjørnskov et al. (2008) who found no significant effect, and of Verme (2011) who presented a negative realtionship between income inequality and well-being. In this respect, it is clear that the established relationship is highly sensentive for the selection of countries, as Berg and Veenhoven (2010) stated. In our study, for instance, we could ascertain a negative relationship when investigating European countries solely.

These differing effects found in various studies underscore that income inequality does not influence all people equally. In our study we therefore tested various hypotheses on

\footnotetext{
5 A positive effect of income inequality on subjective well-being in a large international sample is reported by Haller and Hadler (2006). However, they provide the reader with additional explanations for this positive effect. Among others, the unequal but happy Latin American countries are portrayed as exceptions. Because of these explanations, which they do not test simultaneously, Haller and Hadler conclude (later on) that inequality decreases well-being.
} 
conditional effects: In which countries and for which people does income inequality matter? We thus expected that individual features, as well as a nation's characteristics, condition the way a country's income inequality relates to individual subjective well-being. First, at the individual level it is found that holding egalitarian norms and trust in others are important factors. In countries with large income differences, people who prefer equality seem to experience lower levels of subjective well-being compared to people with less egalitarian norms. This confirms notions from cognitive dissonance theory in which it is proclaimed that people will generally bring their norms in accordance with reality, or otherwise will develop tension and stress. It is interesting that trustful people seem to be less happy about high income disparities than people scoring low on social trust; the positive effect between income inequality and subjective well-being is weaker for trustful people. This supports the idea that for trustful individuals, solidarity with vulnerable groups in society leads to lower well-being than it does for distrusting individuals. Second, at the national level social and institutional trust proved to be strong conditioners. When a country holds high trust levels, citizens seem to be more adverse to income inequality; large income inequality in a high-trusting country leads to lower well-being among the population. Apparently, high national trust creates an atmosphere in which people feel responsible for each other. This makes them less happy in unequal societies. To sum, our results accentuate that the relationship between income inequality and well-being indeed has to be studied under various conditions. Only then it may become clearer when and why inequality has negative or positive effects. Our study is a first endeavor in this direction.

Surely our study has some drawbacks and may be complemented in several ways. First, we foresee progress in increasing our study's generalizability by employing information on more (developing) countries, as well as by using innovative longitudinal data. Second, especially using a prospective design makes it possible to actually solve issues of causality. For instance, it may be determined whether egalitarian norms and trust actually precede feelings of well-being. Third, the measurement of subjective well-being is not without controversy. Issues of cross-cultural validity and the incomparability of answer categories and questions are well described. In this study, we used the only two questions on wellbeing available in the World Values Survey and European Value Surveys. Future research may want to utilize various measures of well-being to investigate conditional effects.

All in all, our research underscores that there are far-reaching effects of (individual and national) trust on the relation between income inequality and people's well-being all over the world. So, governments that wish to improve feelings of well-being in their population may want to develop policy measures directed at the level of trust in their country in accordance to policy measures directed at low income inequalities.

\section{References}

Alesina, A., Di Tella, R., \& MacCulloch, R. (2004). Inequality and happiness: Are Europeans and Americans different? Journal of Public Economics, 88, 2009-2044.

Baker, L. A., Cahalin, L. P., Gerst, K., \& Burr, J. A. (2005). Productive activities and subjective well-being among older adults: The influence of number of activities and time commitment. Social Indicators Research, 73, 431-458.

Bay, A. H., \& Pedersen, A. W. (2006). The limits of social solidarity: Basic income, immigration and the legitimacy of the universal welfare state. Acta Sociologica, 49(4), 419-436.

Beja, E. (2011). Subjective well-being approach to the valuation of income inequality. MPRA Paper No. 34177.

Berg, M., \& Veenhoven, R. (2010). Income inequality and happiness in 119 nations: In search for an optimum that does not appear to exist. In B. Greve (Ed.), Social policy and happiness in Europe. Cheltenham: Edward Elgar. 
Biancotti, C., \& D’Alessio, G. (2008). Values, inequality and happiness. In Temi di discussione: Bank of Italy, Economic and Financial Statistics Department.

Bjørnskov, C., Dreher, A., \& Fischer, J. A. V. (2008). Cross-country determinants of life satisfaction: Exploring different determinants across groups in society. Social Choice and Welfare, 20, 119-173.

Bjørnskov, C., Dreher, A., Fischer, J., \& Schnellenbach J. (2010). Inequality and happiness: When perceived social mobility and economic reality do not match. CEIS Tor Vergata Research Paper Series 8 (5).

Clark, A. E. (2003). Inequality aversion and income mobility: A direct test. In Delta Working Papers, 11.

Clark, A. E., Frijters, P., \& Shields, M. A. (2008). Relative income, happiness, and utility: An explanation for the Easterlin paradox and other puzzles. Journal of Economic Literature, 46(1), 95-144.

Coleman, J. S. (1988). Social capital in the creation of human capital. American Journal of Sociology, 94, 95-120.

Cramer, C. (2003). Does inequality cause conflict? Journal of International Development, 15, $397-412$.

De Haan, J., \& Sturm, J. (2000). On the relationship between economic freedom and economic growth. European Journal of Political Economy, 16, 215-241.

Delhey, J., \& Newton, K. (2005). Predicting cross-national levels of social trust: Global pattern or Nordic exceptionalism. European Sociological Review, 21(4), 311-327.

Easterlin, R. (2001). Income and happiness, towards a unified theory. Economic Journal, 111, $465-484$.

Fahey, T., \& Smyth, E. (2004). Do subjective indicators measure welfare? Evidence from 33 European societies. European Societies, 6(1), 5-27.

Festinger, L. (1957). A theory of cognitive dissonance. Stanford: Stanford University Press.

Fischer, J. A. V. (2009). The welfare effects of social mobility. In OECD Social, Employment and Migration Working Papers 93: OECD, Directorate for Employment, Labour and Social Affairs.

Friedman, M. (1962). Capitalism and freedom. Chicago: University of Chicago Press.

Goldstein, H., Carpenter, J., Kenward, M., \& Levin, K. (2009). Multilevel models with multivariate mixed response types. Statistical Modelling, 9(3), 173-197.

Graham, C., \& Felton, A. (2005). Does inequality matter to individual welfare: An initial exploration based on happiness surveys from Latin America. In Center on Social and Economic Dynamics Working Papers No. 38. Washington, DC: The Brookings Institution.

Graham, C., \& Pettinato, S. (2002). Happiness and hardship: Opportunity and insecurity in new market economies. Washington, DC: The Brookings Institution Press.

Greenfield, E. A., \& Marks, N.F. (2004). Formal volunteering as a protective factor for older adult's psychological well-being. Journals of Gerontology: Series B: Psychological Sciences and Social Sciences $59 b: 258-64$.

Gustavsson, M., \& Jordahl, H. (2008). Inequality and trust in Sweden: Some inequalities are more harmful than others. Journal of Public Economics, 92, 348-365.

Hagerty, M. R. (2000). Social comparisons of income in one's community: Evidence from national surveys of income and happiness. Journal of Personality and Social Psychology, 78(4), 764-771.

Haller, M., \& Hadler, H. (2006). How social relations and structures can produce happiness and unhappiness: An international comparative analysis. Social Indicators Research, 75(2), 169-216.

Heitmeyer, W. (2004). Was treibt die Gesellschaft auseinander? Frankfurt am Main: Suhrkamp.

Hetherington, M. J. (2004). Why trust matters: Declining political trust and the demise of American liberalism. Princeton: Princeton University Press.

Hudson, J. (2006). Institutional trust and subjective well-being across the EU. Kyklos, 59(1), 43-62.

Inglehart, R. (1977). The silent revolution: Changing values and political styles among western publics. Princeton: Princeton University Press.

Inglehart, R. (1990). Culture shift in advanced industrial society. Princeton: Princeton University Press.

Jordahl, H. (2007). Inequality and trust. Research Institute of Industrial Economics (IFN) working paper 715.

Juul, S. (2010). Solidarity and social cohesion in late modernity: A question of recognition, justice and judgement in situation. European Journal of Social Theory, 13(2), 253-269.

Kawachi, I., Kennedey, B. P., Lochner, K., \& Prothrow-Stith, D. (1997). Social capital, income inequality, and mortality. American Journal of Public Health, 87(9), 1491-1498.

Linsen, R., Van Kempen, L., \& Kraaykamp, G. (2011). Subjective well-being in rural India: The curse of conspicuous consumption. Social Indicators Research, 101(1), 57-72.

Lister, M. (2009). Institutions, inequality and social norms: Explaining variations in participation. The British Journal of Politics and International Relations, 9, 20-35.

Luttmer, E. F. P. (2005). Neighbors as negatives: Relative earnings and well-being. The Quarterly Journal of Economics, 20(3), 963-1002.

Maslow, A. H. (1954). Motivation and personality. New-York: Longmann. 
Nannestad, P. (2008). What have we learned about generalized trust, if anything? The Annual Review of Political Scienc, 11, 413-436.

Nieuwehuis, R., Pelzer, B., \& Te Grotenhuis, M. (2009). Manual for influence. ME: Tools for detecting influential data in mixed models Version 0.7 .

Nozick, R. (1974). Anarchy, state, and utopia. New York: Basic Books.

O'Connell, M. (2004). Fairly satisfied: Economic equality, wealth and satisfaction. Journal of Economic Psychology, 25, 297-305.

Portes, A. (2000). The two meanings of social capital. Sociological Forum 15 (1).

Putnam, R. (2000). Bowling alone: the collapse and revival of american community. New-York: Simon \& Schuster.

Ram, R. (2010). Social capital and happiness: Additional cross-country evidence. Journal of Happiness Studies, 11, 409-418.

Rawls, J. (2006) [1971]. Een theorie van rechtvaardigheid [A theory of justice]. Rotterdam Nederlands rechten lemniscaat.

Rodger, J. J. (2003). Social solidarity, welfare and post-emotionalism. Journal of Sociological Policy, 32(3), $403-421$.

Rohstein, B., \& Uslaner, E. M. (2005). All for all: Equality, corruption and social trust. World Politics, 58, 41-72.

Rojas, M. (2007). Heterogeneity in the relationship between income and happiness: A conceptual-referenttheory explanation. Journal of Economic Psychology, 28, 1-14.

Scheepers, P., Gijsberts, M., \& Coenders, M. (2002). Ethnic exclusionism in European counteries: Public opposition to civil rights for legal migrants as a response to perceived ethnic threat. European Sociological Review, 18(1), 17-34.

Schneider, S. M. (2011a). Income inequality and its consequences for life satisfaction: What role do social cognitions play? Social Indicators Research,. doi:10.1007/s11205-011-9816-7.

Schneider, S. (2011). Income inequality and its consequences for life satisfaction: What role do social cognitions play?. Social Indicators Research:1-20.

Schwarze, J., \& Härpfer, M. (2002). Are people inequality averse, and do they prefer redistribution by the state?. Evidence from German Longitudinal Data on Life Satisfaction. IZA Discussion Paper No. 430.

Snijders, T. A. B., \& Bosker, R. J. (1999). Multilevel analysis: An introduction to basic and advanced multilevel modeling. London: Sage Publications.

Svendsen, G. T., \& Bjørnskov, C. (2007). How to construct a robust measure of social capital: Two contributions. Journal of Comparative Policy Analysis: Research and Practice, 9(3), 275-292.

Tomes, N. (1986). Income distribution, happiness and satisfaction: A direct test of the interdependent preferences model. Journal of Economic Psychology, 7, 425-446.

Veenhoven, R. (1984). Conditions of happiness. Dordrecht: Kluwer.

Veenhoven, R. (2008). Sociological theories of subjective well-being. In M. Eid \& R. J. Larsen (Eds.), The science of subjective well-being. New York/London: The Guilford Press.

Verme, P. (2011). Life satisfaction and income inequality. Review of Income and Wealth, 57(1), 111-137.

Wilkinson, R., \& Picket, K. (2009). The spirit level why more equal societies almost always do better. London: Penguin.

WVS. (1981-2008). World Value Survey Official Aggregate v.20090901, 2009. World Values Survey Association (www.worldvaluessurvey.org). Aggregate File Producer: ASEP/JDS, Madrid. 